\title{
GENOTYPE BY ENVIRONMENT INTERACTIONS FOR SEED YIELD AND OIL CONTENT IN SUNFLOWER (H. annuus L.) USING AMIMI MODEL
}

Marinković, R. , Jocković, M., Marjanović-Jeromela, A., Jocić, S., Ćirić, M., Balalić, I. and Sakač, Z.

Institute of Field and Vegetable Crops, Oil Crops Department, Maksima Gorkog 30, 21000 Novi Sad, Republic of Serbia

Received: May 10, 2011

Accepted: June 30, 2011

SUMMARY

Stability of 25 new sunflower hybrid combinations was compared against three standard hybrids in three locations. Seed yield per unit area and oil content in seed were measured using AMMI analysis. The tested combinations showed significant variations in seed yield ( $\mathrm{t} \mathrm{ha}^{-1}$ ) and oil content in seed (\%) from one location to another and within individual locations. Variations in seed yield were mostly due to the impact of location, while the variations in oil content were prevalently due to genotypic differences among the hybrids. The highest and lowest average total yields were obtained by the hybrids G20 and G1, respectively.

The hybrids G17, G8, G2 and G21 showed the widest adaptability. Slightly narrower adaptability was exhibited by the hybrids G4, G7, G13, G14, etc. The hybrids G6, G16, G15 and G22 showed the narrowest adaptability, i.e., they were considerably affected by the analyzed interactions.

The highest and lowest average oil contents were recorded in the hybrids G23 and G28, respectively. The hybrids G7, G11 and G23 demonstrated the highest adaptability for oil content in seed. The lowest adaptability was demonstrated by the hybrids G1 and G16.

Key words: sunflower, AMMI statistical analysis, genotype-environment interaction, seed yield, oil content

\section{INTRODUCTION}

Sunflower hybrids based on $\mathrm{cms}$ predominate in most sunflower-growing countries in the world. Cultivars are grown along with hybrids in a few countries only. Cultivars are typically used in regions with poor environmental conditions and outdated production technology.

* Corresponding author: Phone: ++381214898 410; Fax: ++381216413 833;

e-mail: radovan.marinkovic@ifvcns.ns.ac.rs 
Understandably, growers and breeders are mainly concerned with crop yield and yield stability. Yield performance depends on the genetic yield potential, i.e., all those desirable genes that have been incorporated into a cultivar in the course of the breeding process. Yield stability depends on the cultivar's capacity to react to environmental conditions. It is also referred to as phenotypic plasticity (Bradshaw, 1965), which is determined by the cultivar's genetic composition, i.e., by mutual reaction of its genotypes as individuals and the population as an environment (Borojević, 1981).

The key question of adaptive selection is how to treat mutual relations between genotype and environment. Basic aspects of this relation concern the assessment of adaptive capacity and stability of phenotypes in different environments and the assessment of the environment's suitability as a background for selection. The first question raises much greater attention of researchers, and the other is studied to a much lesser degree although it is not less important than the first one (Kilčevskij and Hotileva, 1989).

Most stable sunflower hybrids for specific conditions of different regions are identified using different models of the genotype/environment interaction analysis. If we want to assess the main, additive effects, an additive model can be used. If, however, we want to do a more detailed analysis of non-additive effects such as genotype/environment interaction, a multiplicative method (PCA) is used.

In case of experiments with full effects on the experimental object, which require a detailed analysis of variation sources through maximally precise partitioning of the total sum of squares, these two methods can be combined. This is the principle of the AMMI analysis - the analysis of additive main effects and multiplicative interactions (Zobel et al., 1988; Cornelius, 1993; cit. by Dimitrijević and Petrović, 2005).

The objective of this study was to identify, using the AMMI analysis, those new genotypes that possess high stability in terms of seed yield and oil content in seed.

\section{MATERIAL AND METHOD}

The material used in this study were 25 new hybrid combinations and three commercial hybrids, NS-H-111, Šumadinac and Sremac, which served as standards. The standards belonged to different maturity groups, and also had different genetic potentials for seed yield and oil content. The hybrid combinations were obtained by crossing five female lines with five male lines. Each female line was crossed with the five male lines.

The material was planted in 2008 in the locations Rimski Šančevi, Kula near Požarevac and Šupljak near Subotica. The soil types in the respective locations were a degraded chernozem, podzol, and a sandy chernozem. The machine sowing was performed in a randomized block design, in three replications. Each combina- 
tion was sown in four rows. The size of the experimental unit was $4 \times 2.8 \mathrm{~m}$. Plant spacing was $0.7 \mathrm{~m}$ between rows and $0.24 \mathrm{~m}$ in the row.

Conventional cultural practices for sunflower were applied in the experiments. Stubble was plown under immediately after wheat harvest. Primary tillage was performed in September. In the locations Rimski Šančevi and Kula, $300 \mathrm{~kg}$ of NPK fertilizers ( $15: 15: 15$ ) were applied before primary tillage. In the location of Šupljak, manure was applied in the amount of $20 \mathrm{t} \mathrm{ha}^{-1}$. Primary tillage was done to a depth of $25 \mathrm{~cm}$ in all three locations. Seedbed preparation was performed from 1 to 4 April.

The herbicides Triflur $21 \mathrm{ha}^{-1}+$ Talstar $0.81 \mathrm{ha}^{-1}$ were pre-sowing incorporated in all three locations. Prometrine $1.51 \mathrm{ha}^{-1}+$ Racer $11 \mathrm{ha}^{-1}$ were used for post-sowing treatment. Thinning was done in the phase of 2 - 3 pairs of permanent leaves. Two between-row cultivations were done in the course of the growing season, the first in the phase of three pairs of permanent leaves, the second in the phase of four pairs of permanent leaves.

The experiments were harvested with a combine harvester Wintersteiger-Expert in all three locations. The sample size was 76 plants per replication or 304 plants for the experiment. Oil content was determined by the NMR method.

Genotype by environment interactions were determined by the AMMI model acording to Zobel et al. (1988). All characteristics of each combination were displayed in a single chart by the biplot technique according to Gabriel (1971).

\section{RESULTS AND DISCUSSION}

The tested combinations showed significant variation in seed yield ( $\mathrm{t} \mathrm{ha}^{-1}$ ) both per single location and for the three observed locations (Table 1). In the location of Rimski Šančevi, seed yields ranged from 3.975 to $5.678 \mathrm{t} \mathrm{ha}^{-1}$, in Kula from 2.025 to $3.997 \mathrm{t} \mathrm{ha}^{-1}$ and in Šupljak from 3.206 to $4.564 \mathrm{t} \mathrm{ha}^{-1}$. The highest and the lowest mean values for the three locations were exhibited by the combinations GT-VL$18 \mathrm{~A} \times$ RHA-MR-10 and L-26 $\times$ RHA-PR-15, respectively. Considering the yield performance per location, the highest yields were obtained at Rimski Šančevi, the lowest in Kula.

Considering the performance of the standards in the three locations, NS-HSremac was the best performer while NS-H-111 had the lowest seed yield. The standards and the new combinations responded similarly to the environment. They had highest yields in the location of Rimski Šančevi and lowest in Kula. At Rimski Šančevi, only three combinations brought higher yields than the standard Sremac, thirteen new combinations outyielded Šumadinac and 17 outyielded NS-H-111.

In the location of Kula, NS-H-111 was the best performing standard. Four new hybrid combinations performed better than NS-H-111, seven combinations outyielded Šumadinac and 10 outyielded Sremac. 
In the location of Šupljak, the highest seed yield was found in Šumadinac, the lowest in NS-H-111. Four combinations performed better than Šumadinac, 10 combinations were better than Sremac and 18 were better than NS-H-111.

Table 1: Mean seed yields ( $\mathrm{t} \mathrm{ha}^{-1}$ ) of the 25 hybrid combinations and three standard sunflower cultivars in the 3 locations

\begin{tabular}{|c|c|c|c|c|c|c|}
\hline \multirow{2}{*}{ No. } & \multirow{2}{*}{ Combination } & \multicolumn{3}{|c|}{ Location } & \multirow{2}{*}{$\bar{X}$} & \multirow{2}{*}{ IPCAg } \\
\hline & & Rimski Šančevi & Kula & Šupljak & & \\
\hline 1 & L-26 $\times$ RHA-NR-15 & 3.936 & 2.025 & 3.565 & 3.175 & -0.223 \\
\hline 2 & NIL-RM-43 × RHA-NR-15 & 4.510 & 3.051 & 4.161 & 3.907 & -0.050 \\
\hline 3 & CMS-IZ $1 \times 2 \times$ RHA-NR-15 & 3.863 & 3.420 & 3.644 & 3.642 & 0.359 \\
\hline 4 & OD-2A $\times$ RHA-NR-15 & 4.159 & 3.320 & 3.206 & 3.562 & 0.055 \\
\hline 5 & BT-VL-18A $\times$ RHA-NR-15 & 4.204 & 3.117 & 4.090 & 3.804 & 0.140 \\
\hline 6 & NIL-RM-43 × RHA-NR-20 & 3.825 & 3.167 & 4.273 & 3.755 & 0.421 \\
\hline 7 & CMS-IZ $1 \times 2 \times$ RHA-NR-20 & 3.979 & 2.992 & 3.388 & 3.453 & 0.076 \\
\hline 8 & L-26 × RHA-NR-20 & 4.713 & 3.566 & 3.794 & 4.024 & -0.054 \\
\hline 9 & OD-2A $\times$ RHA-NR-20 & 3.980 & 3.343 & 3.709 & 3.678 & 0.276 \\
\hline 10 & BT-VL-18A $\times$ RHA-NR-20 & 4.288 & 3.492 & 3.426 & 3.735 & 0.090 \\
\hline 11 & NIL-RM-43 × RHA-Z & 3.922 & 3.290 & 3.810 & 3.674 & 0.311 \\
\hline 12 & CMS-IZ $1 \times 2 \times$ RHA-Z & 4.251 & 3.282 & 4.082 & 3.872 & 0.173 \\
\hline 13 & $\mathrm{~L}-26 \times \mathrm{RHA}-\mathrm{Z}$ & 4.476 & 3.140 & 3.640 & 3.752 & -0.107 \\
\hline 14 & $\mathrm{OD}-2 \mathrm{~A} \times \mathrm{RHA}-\mathrm{Z}$ & 4.828 & 3.556 & 3.838 & 4.074 & -0.116 \\
\hline 15 & BT-VL-18A $\times$ RHA-Z & 5.678 & 3.474 & 3.934 & 4.362 & -0.626 \\
\hline 16 & NIL-RM-43 $\times$ RHA-MR-10-G 16 & 4.489 & 3.992 & 4.525 & 4.335 & 0.394 \\
\hline 17 & CMS-IZ $1 \times 2 \times$ RHA-MR-10 & 4.765 & 3.608 & 3.948 & 4.107 & -0.036 \\
\hline 18 & L-26 $\times$ RHA-MR-10 & 5.019 & 3.657 & 4.076 & 4.251 & -0.139 \\
\hline 19 & OD-2A $\times$ RHA-MR-10 & 4.774 & 3.079 & 3.910 & 3.921 & -0.247 \\
\hline 20 & BT-VL-18A $\times$ RHA-MR-10 & 5.338 & 3.835 & 4.564 & 4.579 & -0.156 \\
\hline 21 & NIL-RM-43 × RHA-MR-63 & 4.410 & 3.107 & 3.741 & 3.752 & -0.059 \\
\hline 22 & L-26 × RHA-MR-63 & 5.177 & 2.752 & 4.226 & 4.052 & -0.539 \\
\hline 23 & CMS-IZ $1 \times 2 \times$ RHA-MR-63 & 4.583 & 3.475 & 4.250 & 4.103 & 0.086 \\
\hline 24 & OD-2A $\times$ RHA-MR-63 & 4.411 & 3.468 & 4.223 & 4.034 & 0.179 \\
\hline 25 & BT-VL-18A $\times$ RHA-MR-63 & 5.094 & 3.504 & 3.837 & 4.145 & -0.291 \\
\hline 26 & NS-H-111 & 4.222 & 3.582 & 3.594 & 3.799 & 0.198 \\
\hline 27 & NS-H-Šumadinac & 4.411 & 3.519 & 4.245 & 4.058 & 0.202 \\
\hline 28 & NS-H-Sremac & 5.131 & 3.464 & 3.880 & 4.159 & -0.319 \\
\hline & $\bar{X}$ & 4.516 & 3.331 & 3.914 & 3.920 & \\
\hline & $\sigma^{2}$ & 0.318 & 0.244 & 0.287 & 0.515 & \\
\hline & IPCAe & -1.105 & 0.705 & 0.399 & & \\
\hline
\end{tabular}

LSD 5\% $=0.44$

$\operatorname{LSD} 1 \%=0.58$

On average for all the locations, the combination L-26 $\times$ RHA-MR-63 displayed the highest variation in seed yield. The combinations CMS-OF-1 $\times 2 \times$ RHA-PR-15 and OD-2A $\times$ RHA-NR-20 had the least variable seed yields. 
The results of the AMMI analysis of variance for the seed yield showed that both additive effects (genotype and environmental conditions) as well as their interaction had highly significant proportions in the total variance of the experiment. The genotype and environmental conditions were responsible for $82.38 \%$ of the variance and their interaction was responsible for $17.62 \%$ of the variance. A significantly higher portion of the sum of squares of the variance belonged to environmental conditions than to the genotype, $60.16 \%$ and $22.22 \%$, respectively. A detailed analysis of the major components of variance nevertheless showed that $61.45 \%$ of this interaction was agronomically significant and defined by the first principal component (IPCA1). The other components that did not show a significant effect on the variance of the interaction were considered as agronomically irrelevant and were placed among the other effects (36.78\%) (Table 2). Similar results were reported by Krizmanić et al. (2010) and Marinković et al. (2011).

Table 2: AMMI analysis of variance for seed yields of the 28 hybrid combinations

\begin{tabular}{|c|c|c|c|c|c|c|}
\hline \multirow{2}{*}{ Source of variation } & \multirow{2}{*}{ D. F. } & \multirow{2}{*}{ S. S. } & \multirow{2}{*}{ M. S. } & \multirow{2}{*}{ F-value } & \multicolumn{2}{|c|}{ F-table } \\
\hline & & & & & 0.01 & 0.05 \\
\hline Block & 6 & 2.21 & 0.368 & 2.04 & 2.09 & 2.80 \\
\hline Treatment & 83 & 97.92 & 1.180 & $6.54^{\star \star}$ & 1.00 & 1.00 \\
\hline Genotype & 27 & 21.76 & 0.806 & $4.47^{\star \star}$ & 1.46 & 1.69 \\
\hline Environment & 2 & 58.91 & 29.457 & $80.13^{\star *}$ & 2.99 & 4.60 \\
\hline Interaction & 54 & 17.25 & 0.320 & $1.77^{\star \star}$ & 1.00 & 1.00 \\
\hline IPCA1 & 28 & 10.60 & 0.379 & $2.10^{\star \star}$ & 1.46 & 1.69 \\
\hline Residue & 26 & 6.65 & 0.256 & 1.42 & 1.46 & 1.69 \\
\hline Error & 162 & 29.22 & 0.180 & & & \\
\hline Total & 251 & 129.35 & 0.515 & & & \\
\hline
\end{tabular}

In a very informative two-dimensional graph, which displays the results from Table 1, the average values (GX, and Ex) were entered on the abscissa and the values of the first principal component (PCAg, i.e., PCAe) were entered on the ordinate (Figure 1). As Gauch and Zobel (1997) claimed that the effects of the genotype (abscissa) control the wide-sense adaptability while interaction effects (ordinate) control the narrow-sense adaptability, it can be concluded that the combinations G17, G8, G2 and G21 had the widest adaptability. The combinations G4, G7, G13, G14, etc., showed a somewhat narrower adaptability. The combinations G6, G16, G15 and G22 demonstrated the narrowest adaptability, i.e., these combinations exhibited a high effect of the interaction. The combinations G18 and G20 stood out for high adaptability and high yields, considerably above the average for the experiment.

All hybrid combinations that are positioned above the abscissa, i.e., which have a positive sign, showed a positive interaction with the locations Kula and Supljak. The combinations that are positioned below the abscissa, i.e., those with a negative sign, showed a positive interaction with the location of Rimski Šančevi. The stand- 
ards showed an intermediate adaptability. NS-H-111 and Šumadinac showed a positive interaction with the locations Kula and Šupljak, Sremac with the location Rimski Šančevi.
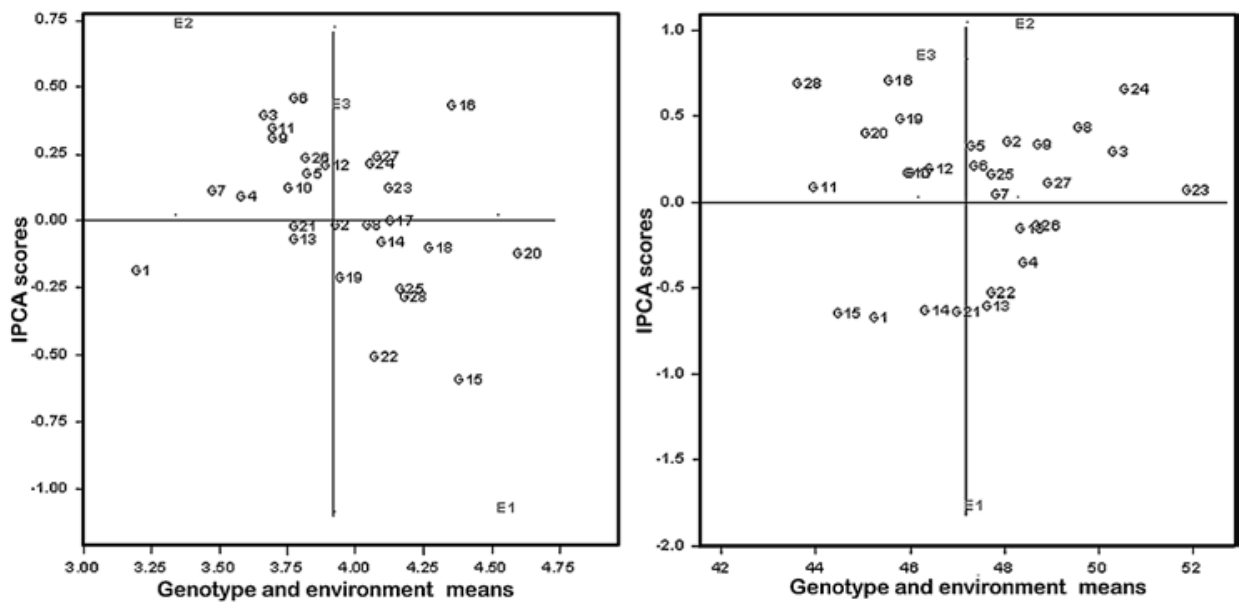

Figure 1: Estimate of the effect of genotype Figure 2: Estimate of the effect of genotype to environment interaction on seed yields of the 28 sunflower hybrid to environment interaction on oil combinations in three locations content of the 28 sunflower hybrid combinations in three locations

The studied combinations differed significantly in the oil content per experiment location (Table 3). The highest oil content, taking into account all three locations, was found in the combination CMS-IZ $1 \times 2 \times$ RHA-MR-63 (51.74\%). In the location of Rimski Šančevi, the oil content ranged from $43.80 \%$, in the combination NIL-RM-43 $\times$ RHA-Z, to 51.77\%, in the combination CMS-IZ $1 \times 2 \times$ RHA-MR-63. The latter combination had a highly significant oil content in respect to all other hybrid combinations and the standards. The standards behaved similarly. Three hybrid combinations had a significantly higher oil content than NS-H-111 and one had a highly significant content. The situation was similar with the standard Šmadinac. Finally, all hybrid combinations under study had a highly significant oil content in relation to the standard Sremac.

The highest average oil content of the examined combinations was registered in the location of Kula. The oil contents ranged from $45.60 \%$, in the combination NILRM-43 $\times$ RHA-Z, to 53.93\%, in the combination CMS-IZ $1 \times 2 \times$ RHA-MR-63. It should be noted that the same hybrid combinations had the lowest and highest oil contents in this and the previously discussed location. The standard Šumadinac had the highest oil content, Sremac the lowest. Three hybrid combinations had the oil content above 50\% in this location. The combination CMS-IZ $1 \times 2 \times$ RHA-MR63 had a highly significant oil content in relation to all other combinations and the standards. The combination OD-2A $\times$ RHA-MR-63 was a highly significant oil content in relation to 21 combination and significant oil content in relation to 22 com- 
binations. Four hybrid combinations had highly significant oil contents compared with the standards NS-H-111 and Šumadinac. Twenty-two combinations had highly significant content compared with the standard Sremac.

Table 3: Mean values of oil content (\%) in seed of the 25 hybrid combinations and three sunflower standards in three locations

\begin{tabular}{|c|c|c|c|c|c|c|}
\hline Hybrid combination & Rimski Šančevi & Kula & Šupljak & $\overline{\mathrm{X}}$ & IPCAg1 & IPCAg2 \\
\hline L-26 × RHA-NR-15 & 46.53 & 47.07 & 41.73 & 45.11 & -0.8334 & -0.7272 \\
\hline NIL-RM-43 × RHA-NR-15 & 47.27 & 48.17 & 48.37 & 47.93 & 0.5872 & 0.2957 \\
\hline CMS-IZ $1 \times 2 \times$ RHA-NR-15 & 49.70 & 51.10 & 49.80 & 50.20 & 0.2136 & 0.2366 \\
\hline OD-2A $\times$ RHA-NR-15 & 49.00 & 49.13 & 46.70 & 48.28 & -0.1002 & -0.4066 \\
\hline BT-VL-18A $\times$ RHA-NR-15 & 46.60 & 48.10 & 46.80 & 47.17 & 0.2155 & 0.2730 \\
\hline NIL-RM-43 × RHA-NR-20 & 46.83 & 47.33 & 47.57 & 47.24 & 0.5880 & 0.1555 \\
\hline CMS-IZ $1 \times 2 \times$ RHA-NR-20 & 47.60 & 47.80 & 47.67 & 47.69 & 0.4886 & -0.0126 \\
\hline L-26 × RHA-NR-20 & 48.70 & 50.80 & 48.83 & 49.44 & 0.0566 & 0.3843 \\
\hline OD-2A $\times$ RHA-NR-20 & 47.97 & 48.93 & 48.87 & 48.59 & 0.5203 & 0.2771 \\
\hline BT-VL-18A $\times$ RHA-NR-20 & 45.60 & 47.37 & 44.47 & 45.81 & -0.1881 & 0.1129 \\
\hline NIL-RM-43 × RHA-Z & 43.80 & 45.60 & 42.13 & 43.84 & -0.3322 & 0.0339 \\
\hline CMS-IZ $1 \times 2 \times$ RHA-Z & 46.00 & 47.33 & 45.57 & 46.30 & 0.0931 & 0.1373 \\
\hline L-26 × RHA-Z & 48.63 & 47.60 & 46.27 & 47.50 & 0.1584 & -0.6545 \\
\hline $\mathrm{OD}-2 \mathrm{~A} \times \mathrm{RHA}-\mathrm{Z}$ & 47.67 & 49.60 & 41.37 & 46.21 & -1.5474 & -0.6837 \\
\hline BT-VL-18A $\times$ RHA-Z & 45.53 & 44.00 & 43.50 & 44.34 & 0.3617 & -0.7026 \\
\hline NIL-RM-43 $\times$ RHA-MR-10 & 44.30 & 48.30 & 43.70 & 45.43 & -0.5796 & 0.6527 \\
\hline CMS-IZ $1 \times 2 \times$ RHA-MR-10 & 45.70 & 47.57 & 44.43 & 45.90 & -0.2458 & 0.1118 \\
\hline L-26 $\times$ RHA-MR-10 & 48.63 & 49.77 & 46.30 & 48.23 & -0.3450 & -0.2087 \\
\hline OD-2A $\times$ RHA-MR-10 & 44.97 & 48.53 & 43.50 & 45.67 & -0.6986 & 0.4252 \\
\hline BT-VL-18A $\times$ RHA-MR-10 & 44.33 & 47.23 & 43.20 & 44.92 & -0.4559 & 0.3433 \\
\hline NIL-RM-43 × RHA-MR-63 & 47.93 & 45.20 & 47.50 & 46.88 & 1.0541 & -0.6893 \\
\hline L-26 × RHA-MR-63 & 48.53 & 46.73 & 47.57 & 47.61 & 0.6973 & -0.5853 \\
\hline CMS-IZ $1 \times 2 \times$ RHA-MR-63 & 51.77 & 53.93 & 49.53 & 51.74 & -0.5637 & 0.0174 \\
\hline OD-2A $\times$ RHA-MR-63 & 49.27 & 51.63 & 50.43 & 50.44 & 0.2576 & 0.6046 \\
\hline BT-VL-18A $\times$ RHA-MR-63 & 47.30 & 47.90 & 47.60 & 47.60 & 0.4537 & 0.1061 \\
\hline NS-H-111 & 48.87 & 49.30 & 47.53 & 48.57 & 0.0758 & -0.1902 \\
\hline NS-H-Šumadinac & 48.63 & 49.40 & 48.40 & 48.81 & 0.2781 & 0.0543 \\
\hline NS-H-Sremac & 42.33 & 45.63 & 42.53 & 43.50 & -0.2098 & 0.6390 \\
\hline$\overline{\mathrm{X}}$ & 47.14 & 48.25 & 46.14 & 47.18 & & \\
\hline$\sigma^{2}$ & 4.815 & 4.429 & 7.000 & 6.120 & & \\
\hline IPCAe1 & -0.1576 & -1.9453 & -2.1029 & & & \\
\hline IPCAe2 & -1.8229 & 1.0179 & 0.8049 & & & \\
\hline
\end{tabular}

LSD $(5 \%)=0.73$

$\operatorname{LSD}(1 \%)=0.96$

The average oil content of the tested hybrid combinations and standards was lower in the location of Supljak than in the other two locations. The difference was $1 \%$ in favour of the location of Rimski Šančevi and almost $2 \%$ in favour of the location of Kula. Some hybrid combinations performed as well in this as in the other 
two locations, but most of them had a lower oil content in Šupljak. The combinations OD-2A $\times$ RHA-Z and L2 $6 \times$ RHA-NR-15 had lowest oil contents $(41.37 \%$ and $41.73 \%$, respectively), the combination OD-2A $\times$ RHA-MR-63 the highest $(50.43 \%)$. The combination OD-2A $\times$ RHA-MR-63 had highly significant oil content compared with 22 hybrid combinations and all three standards. This hybrid combination had high oil contents in the other two locations, too. Besides this combination, six others had high oil contents in all three locations. The standard Sremac had the lowest oil content (42.53\%) in this location. The content of the standard NS-H-111 was significantly higher $(47.53 \%)$ than that of Sremac, and the standard Šumadinac had the highest oil content (48.40\%). Twenty-two hybrid combinations had a significantly higher oil content than the standard Sremac, while 21 combinations and the other two standards had highly significant oil contents in relation to Sremac.

Table 4: AMMI analysis of variance for oil content in seed of the 28 hybrid combinations

\begin{tabular}{|c|c|c|c|c|c|c|}
\hline \multirow{2}{*}{ Source of variation } & \multirow{2}{*}{ D. F. } & \multirow{2}{*}{ S. S. } & \multirow{2}{*}{ M. S. } & \multirow{2}{*}{ F-value } & \multicolumn{2}{|c|}{ F-table } \\
\hline & & & & & 0.01 & 0.05 \\
\hline Block & 6 & 12.8 & 2.13 & $4.38^{\star \star}$ & 2.09 & 2.80 \\
\hline Treatment & 83 & 1444.3 & 17.40 & $35.69 * *$ & 1.00 & 1.00 \\
\hline Genotype & 27 & 978.0 & 36.22 & $74.28^{* *}$ & 1.46 & 1.69 \\
\hline Environment & 2 & 187.9 & 93.95 & $44.01^{* \star}$ & 2.99 & 4.60 \\
\hline Interaction & 54 & 278.5 & 5.16 & $10.58^{* *}$ & 1.00 & 1.00 \\
\hline IPCA1 & 28 & 203.3 & 7.26 & $14.89 * *$ & 1.46 & 1.69 \\
\hline IPCA2 & 26 & 75.2 & 2.89 & $5.93^{\star \star}$ & 1.46 & 1.69 \\
\hline Residue & 0 & 0,0 & & & & \\
\hline Error & 162 & 79.0 & 0.49 & & & \\
\hline Total & 251 & 1536.2 & 6.12 & & & \\
\hline
\end{tabular}

In the analysis of variance, the sum of squares for the treatment was divided into sums of squares for the genotype, environmental conditions and their interaction, the last two serving as sources of variation. The analysis indicated that all three sources of variation were highly significant. The main effects, genotype and environmental conditions, took $80.72 \%$ of the sum of squares for the experiment, the genotype/environment interaction took $19.28 \%$. Similar results were reported by Dijanović et al. (2004) and Marinković et al. (2011). Marjanović-Jeromela et al. (2008) and Radić et al. (2008) reported a large importance of environmental conditions. Increased importance of environmental conditions, but for oil yield, was observed by Balalić et al. (2010). These authors stated that the impact of hybrids was very low $-10.70 \%$.

Further analysis of the interaction showed that the first component, IPCA1, was dominant, explaining $73.00 \%$ of the interaction, while the second component, IPCA2, explained $23.00 \%$ of the interaction (Table 4 ).

The following figure, which presents the seed oil content, showed that the hybrid combinations G7, G11 and G23 showed the highest adaptability, the combi- 
nations G1 and G16 the lowest. The combination G23 had the highest oil content, the combination G11 the lowest. The position of the combination G7 in relation to the abscissa indicates that it had similar oil contents in all locations (Table 3). A much larger number of combinations was positively correlated with the location of Kula and Šupljak. Among the standards, NS-H-111 exhibited the highest adaptability, Sremac the lowest (Figure 2).

\section{CONCLUSIONS}

Based on the results of experiments performed in three locations, it was concluded that the variation of seed yield was mainly caused by the location, i.e., by the different climatic and edaphic conditions, while the variation of oil content was mainly under the effect of genotypic differences among the hybrids. The results of the experiment indicated that the non-additive effect (interaction) had a much smaller share of variation of the examined characteristics.

The hybrid combination G20 had the highest average total yield of seed, the combination G1 the lowest.

The combinations G17, G8, G2 and G21 had the highest adaptability, followed by the combinations G4, G7, G13, G14, etc. The combinations G6, G16, G15 and G22 had the lowest adaptability, i.e., these combinations exhibited a high interaction.

The hybrid combination G23 had the highest average oil content, the combination G28 the lowest.

The hybrid combinations G7, G11 and G23 demonstrated the highest adaptability for the oil content in seed, the combinations G1 and G16 the lowest.

\section{ACKNOWLEDGEMENT}

The data treated in this paper were obtained within the project TR31025, funded by the Ministry of Science and Technological Development of the Republic of Serbia.

\section{REFERENCES}

Balalić, I.M., Crnobarac, J.Ž., Miklič, J.V., 2010. Interaction hybrid $\times$ planting data for oil yield in sunflower. J. of Agricultural Sci. Vol. (1): 9-16.

Borojević, S., 1981. Principi i metodi oplemenjivanja bilja. Ćirpanov, (Novi Sad: Prosveta). P. 1-386.

Bradshaw, A.D., 1965. Evolutionary significance of phenotypic plasticity in plants. Adv. in Genetics 13: 115-155.

Cornelius, P.L., 1993. Statistical test and retention of terms in the additive main effects and multiplicative interaction model for cultivar trials. Crop Sci. 33: 1186-1193.

Dijanović, D., Kraljević-Balalić, M., Stanković, V. and Mihajlović, I., 2004. Stability parameters of oil and protein content in protein sunflower lines. In: G.J. Seiler [ed.], Proc. $16^{\text {th }}$ Intl. 
Sunflower Conf., Fargo, ND, USA, 29 August-4 September 2004. Intl. Sunflower Assoc., Paris, France. Vol. II: 573-579.

Dimitrijević, M., Petrović, S., 2005. Genetika populacije - adaptibilnost i stabilnost genotipa. "Talija graf", Novi Sad.

Gauch, H. G., Zobel, R.W., 1997. Identifying mega-environments and targeting genotypes. Crop Sci. 37: 311-326.

Kilčevskij, A.V., Hotileva, L.V., 1989. Genotip i sreda v selekcii rastenij (knjiga). "Nauka i tehnika“,Minsk.

Krizmanić, G., Krizmanić, M., Guberac, V., Marić, S., Šimić, D., 2010. AMMI analiza za prinose zrna i ulja kod hibrida suncokreta. Zbornik radova, Poljoprivredni Fakutet Sveučilišta Josipa Jurja Štrossmayera, Osijek, 83-84.

Marjanović-Jeromela, Ana, Marinković, R., Mijić, A., Jankulovska, Mirjana, Zdunić, Z. and Nagl, Nevena, 2008. Oil yield stability of winter rapeseed (Brassica napus L.) genotypes. Agriculturae Conspectus Scientificus 73: 1-4.

Marinković, R., Jocković, M., Marjanović-Jeromela, Ana, Jocić, S., Ćirić, M., Čanak, P. and Radeka, I., 2011. Stability evaluation of new sunflower (H. annuus L.) hybrids. In: Proc. $52^{\text {nd }}$ meeting of oil processing industry: "Production and processing of oilseeds", Herceg Novi, Montenegro, June 5-10, 2011. Busines association "Industrial plants", Novi Sad, Serbia. 52: 53-62.

Radić, V., Jocić, S., Mrđa, Jelena, 2008. Effect of the enviroment on the chemical composition and other parameters of sunflower seed quality. In: Velasco, L. [ed.], Proc $17^{\text {th }}$ Intl. Sunflower Conf., Cordoba, Spain, 8-12 June 2008. Intl. Sunflower Assoc., Paris, France. 2: 747-750.

Zobel, R.W., Wright, M.J., Gauch, H.G., 1988. Statistical analysis of a yield trial. Agronomy J. 80: $388-393$ 